\title{
Pengaruh Fraud Diamond dan Religiusitas terhadap Kecurangan Akademik Mahasiswa Akuntansi
}

\author{
Lulu Amalia Nusron ${ }^{\bowtie}$, Risa Tika Sari \\ Universitas PGRI Yogyakarta \\ e-mail: lulu.amalia@upy.ac.id
}

\begin{abstract}
Higher education is expected to be able to produce professionals who are able to compete in the era of globalization both in science and in morals, however fraudulent practices are often found in the world of education which is often referred to as academic fraud. This study aims to determine the factors that influence student academic fraud by using the fraud diamond concept and religiosity. Collecting data in this study using online questionnaires and purposive sampling techniques with the criteria of active students who have taken auditing courses 2 . The sample of this study was 80 active students of the Accounting Study Program at Universitas PGRI Yogyakarta, Universitas Negeri Yogyakarta, Universitas Muhammadiyah Yogyakarta, Universitas Teknologi Yogyakarta, and Universitas Sanata Dharma Yogyakarta. Data analysis techniques using multiple linear regression models and data testing using SPSS. The results of this study indicate that opportunity and rationalization have a significant positive effect on academic cheating while pressure, capability, and religiosity have no effect on academic cheating.
\end{abstract}

Keywords: academic fraud, pressure, opportunity, rationalization, capability, religiosity

\begin{abstract}
Abstrak
Perguruan tinggi diharapkan mampu mencetak tenaga professional yang mampu bersaing dalam era globalisasi baik dalam ilmu pengetahuan maupun akhlak, namun sering ditemukan praktik-praktik kecurangan dalam dunia pendidikan yang sering disebut kecurangan dalam akademik. Tujuan melakukan penelitian ini untuk mengetahui penyebab kecurangan akademik mahasiswa akuntansi dengan menggunakan konsep dari teori fraud diamond dan religiusitas. Data yang dikumpulkan pada penelitian dikumpulkan melalui kuisioner online dengan menggunakan teknik purposive sampling dengan kriteria mahasiswa akuntansi yang telah menempuh mata kuliah pengauditan 2. Sampel penelitian ini sebanyak 80 mahasiswa aktif Program Studi Akuntansi Universitas PGRI Yogyakarta, Universitas Negeri Yogyakarta, Universitas Muhammadiyah Yogyakarta, Universitas Teknologi Yogyakarta dan Universitas Sanata Dharma Yogyakarta. Teknik analisis data dengan menggunakan model regresi linear berganda dan pengujian data dengan menggunakan SPSS versi 24. Hasil penelitian ini menunjukan bahwa kesempatan dan rasionalisasi mempunyai pengaruh positif signifikan terhadap kecurangan akademik sedangkan tekanan, kemampuan, dan religiusitas tidak mempunyai pengaruh terhadap kecurangan akademik.
\end{abstract}

Kata kunci: kecurangan akademik, tekanan, kesempatan, rasionalisasi, kemampuan, religiusitas 


\section{PENDAHULUAN}

Perguruan tinggi diharapkan mampu mencetak tenaga professional yang mampu bersaing dalam era globalisasi baik dalam ilmu pengetahuan maupun akhlak yang berkaitan dengan moral dan etika profesi. Namun fenomena yang sering ditemukan saat ini yaitu praktik-praktik kecurangan yang kerap terjadi pada dunia pendidikan atau bisa disebut kecurangan akademik (academic fraud). Kecurangan akademik adalah suatu upaya tidak jujur dalam mendapatkan keberhasilan, misalnya karena kemudahan akses dari internet sebagai godaan untuk mengakui paper atau sebuah karya orang lain tanpa adanya tanda bahwa itu kutipan. Alasan melakukan kecurangan beragam mulai dari tekanan orang tua, teman, fakultas maupun jurusan demi mendapatkan IPK yang tinggi serta kurang memahami tentang agama. Selain itu keinginan diri sendiri untuk terlihat lebih unggul juga menjadi dorongan yang kuat untuk melakukan kecurangan (Fitriana \& Baridwan, 2012; Munirah \& Nurkhin, 2018)). Kecurangan akademik terjadi karena umumnya mahasiswa hanya berfokus terhadap nilai yang didapat sehingga mahasiswa menempuh beragam cara demi memperoleh hasil yang diinginkan (Prawira \& Irianto, 2018; Santoso \& Yanti, 2016). Kecurangan mahasiswa dalam akademik contohnya mencontek hasil ujian yang dirasa sulit, bekerja sama dengan teman saat ujian, membagikan jawaban dengan tangan, hingga memalsukan daftar pustaka dalam tugas sekolah (Munirah \& Nurkhin, 2018).

Fraud Diamond merupakan konsep yang disampaikan oleh Wolfe \& Hermanson (2004) sebagai pelengkap dari teori yang disampaikan oleh Cressey (1953) yaitu fraud triangle. Fraud diamond terdiri dari empat (4) elemen, yaitu tekanan (pressure), kesempatan (opportunity), rasionalisasi (rationalization), dan kemampuan (capability).

Elemen pertama yaitu tekanan, tekanan adalah kondisi yang mengharuskan seseorang atau merasa didorong untuk melakukan tindakan curang (Artani \& Wetra, 2017). Penelitian Fitriana \& Baridwan (2012) mengungkapkan bahwa tekanan berpengaruh pada kecurangan akademik, namun tidak didukung oleh penelitian Nursani \& Irianto (2013) yang mengungkapkan jika tekanan tidak berpengaruh terhadap perilaku curang mahasiswa.

Elemen kedua adalah kesempatan dan elemen yang ketiga adalah rasionalisasi. Kesempatan adalah peluang dalam melakukan kecurangan entah disengaja maupun tidak disengaja sedangkan rasionalisasi merupakan suatu pemikiran yang membenarkan tindakan yang telah dilakukan (Ristianingsih, 2018). Penelitian Padmayanti dkk. (2017) mengemukakan bahwa kesempatan dan rasionalisasi mempunyai pengaruh terhadap perilaku curang mahasiswa, namun penelitian Budiman (2018) yang menunjukkan bahwa kesempatan dan rasionalisasi tidak mempunyai pengaruh terhadap perilaku curang mahasiswa.

Elemen yang keempat berdasarkan Wolfe \& Hermanson (2004) adalah kemampuan yaitu kecakapan yang dimiliki seseorang, baik dalam hal melihat peluang maupun memanfaatkannya dalam proses kecurangan. Kemampuan memegang peranan penting dalam kecurangan, tanpa kemampuan yang memadai kecurangan sulit terjadi (Neila dkk., 2019). Penelitian Murdiansyah dkk. (2017) mengungkapkan bahwa kemampuan mempunyai pengaruh terhadap perilaku kecurangan akademik, berbeda dengan Zaini dkk., (2015) yang menyatakan bahwa kemampuan tidak memiliki pengaruh terhadap perilaku curang mahasiswa.

Selain itu sering terjadi kasus kecurangan karena kurangnya pengetahuan tentang religiusitas. Padahal semua agama mengajarkan kepada umatnya untuk berbuat kebaikan, dan seluruhnya sepakat bahwa tindakan kecurangan termasuk tindakan yang tercela (Rahmawati \& Susilawati, 2019). Menurut Kamus Besar Bahasa Indonesia, religiusitas diartikan 
sebagai akidah pada Tuhan dalam hal keagamaan. Religiusitas dapat diartikan sebagai pemahaman dari ketaatan agama yang diwujudkan dengan tindakan seharihari. Semakin tinggi religiusitas seseorang semakin rendah pula potensi dalam melakukan kecurangan (Herlyana dkk., 2017). Penelitian terkait dengan religiusitas juga didukung oleh Zamzam dkk. (2017) yang mengungkapkan bahwa religiusitas memiliki pengaruh terhadap kecurangan akademik mahasiswa.

\section{Tekanan}

Tekanan (incentive) ialah kondisi di mana pelaku merasa harus melakukan kecurangan. Semakin tinggi sesuatu yang ingin didapat maka semakin besar pula seorang melakukan hal curang (Albrecht \& Albrecht, 2003).

Mahasiswa melakukan tindakan yang tidak baik sebab memperoleh tekanan dari keluarga, takut dengan nilai yang buruk, dan malu mampu membuat mahasiswa melakukan tindakan curang (Budiman, 2018). Menurut Nursani \& Irianto (2013) tekanan mengharuskan seseorang untuk melakukan kecurangan. Menurut Fitriana \& Baridwan (2012) tekanan dan kecurangan akademik mempunyai pengaruh.

Penelitian berbeda oleh Nursani \& Irianto (2013) yang menunjukkan hasil bahwa tekanan dan kecurangan akademik tidak mempunyai pengaruh karena terdapat perbedaan konteks dari penelitian sebelumnya. Responden tidak merasa mendapatkan tekanan atau dorongan untuk mendapatkan nilai yang bagus. Berdasarkan uraian tersebut maka dirumuskan hipotesis yaitu:

\section{$\mathrm{H}_{1}$ : Tekanan berpengaruh positif signifikan terhadap perilaku kecurangan akademik mahasiswa}

\section{Kesempatan}

Kesempatan adalah keadaan yang membuka peluang untuk suatu tindakan curang. Meningkatnya kesempatan dapat memicu kemungkinan tindakan curang
(Albrecht \& Albrecht, 2003). Penelitian Padmayanti dkk. (2017) mengemukakan kesempatan mempunyai pengaruh terhadap kecurangan akademik. Sebelumnya penelitian Zaini dkk., (2015) mengemukakan bahwa kesempatan dan kecurangan kademik tidak mempunyai pengaruh. Kesempatan tidak mempunyai pengaruh pada kecurangan akademik karena saat ujian berlangsung mahasiswa tidak boleh memilih tempat duduk serta dijaga ketat oleh pengawas sehingga tidak dapat melakukan tindakan curang. Selain itu mahasiswa enggan melakukan tindakan curang karena ancaman mendapat nilai "E" apabila terbukti curang. Berdasarkan uraian di atas maka dirumuskan hipotesis yaitu:

\section{$\mathrm{H}_{2}$ : Kesempatan berpengaruh positif signifikan terhadap perilaku kecurangan akademik mahasiswa}

\section{Rasionalisasi}

Rasionalisasi pada mahasiswa berpengaruh langsung pada pelaku yang senantiasa melakukan pembenaran dari apa yang sudah dilakukan. Pelaku akan membenarkan untuk mengesampingkan ketidak konsistensi antara apa yang dilakukan dan apa yang pelaku ketahui (Ridhayana, 2018). Rasionalisasi membuat pelaku kecurangan mencari pembenaran atas apa yang dilakukannya (Zaini dkk., 2015). Semakin tinggi rasionalisasi semakin tinggi pula kemungkinan melakukan kecurangan (Munirah \& Nurkhin, 2018).

Berdasarkan penelitian Murdiansyah dkk. (2017), rasionalisasi menunjukan pengaruh terhadap kecurangan akademik. Berbanding terbalik dengan yang diteliti Aziz \& Novianti (2016) yang menunjukkan bahwa rasionalisasi tidak mempunyai pengaruh dengan kecurangan akademik. Berdasarkan uraian di atas yang menyatakan rasionalisasi membuat pelaku kecurangan merasa benar dan tidak merasa bersalah terhadap kecurangan yang sudah dilakukan maka dirumuskan hipotesis yaitu: 

$\mathrm{H}_{3}$ : Rasionalisasi berpengaruh positif signifikan terhadap perilaku kecurangan akademik mahasiswa

\section{Kemampuan}

Wolfe \& Hermanson (2004) mengemukakan bahwa tindakan kecurangan tidak bisa terjadi apabila seorang tidak dibekali keahlian melakukan perbuatan curang. Prawira \& Irianto (2018) mengungkapkan semakin tinggi keahlian dalam berbuat curang, maka kemungkinan berbuat curang juga semakin tinggi.

Penelitian Arifah dkk. (2018) menyampaikan bahwa kemampuan dan kecurangan akademik berpengaruh. Berbanding terbalik dengan Zaini dkk. (2015) hasil penelitian tersebut menunjukkan bahwa keahlian tidak mempunyai pengaruh pada kecurangan akademik. Berdasarkan uraian di atas di mana pelaku akan melakukan kecurangan ketika dia merasa mampu dan ahli maka dirumuskan hipotesis yaitu:

\section{$\mathrm{H}_{4}$ : Kemampuan berpengaruh positif signifikan terhadap perilaku kecurangan akademik mahasiswa}

\section{Religiusitas}

KBBI Online mengartikan agama sebagai skema pengatur akidah dan peribadahan pada Tuhan Yang Maha Kuasa serta aturan kaidah kehidupan manusia dan lingkungannya. Pemahaman yang tinggi dianggap mampu mengatur tindakannya dalam berperilaku agar dapat menghalau terjadinya perbuatan (Purnamasari, 2013).

Penelitian Zamzam dkk. (2017) menyampaikan bahwa religiusitas mempunyai pengaruh terhadap kecurangan akademik. Berbanding terbalik penelitian dengan Aziz \& Novianti (2016) yang menunjukan bahwa religiusitas tidak memiliki pengaruh dengan kecurangan. Berdasarkan uraian diatas maka dirumuskan hipotesis yaitu:
H5: Religiusitas berpengaruh negatif terhadap perilaku kecurangan akademik

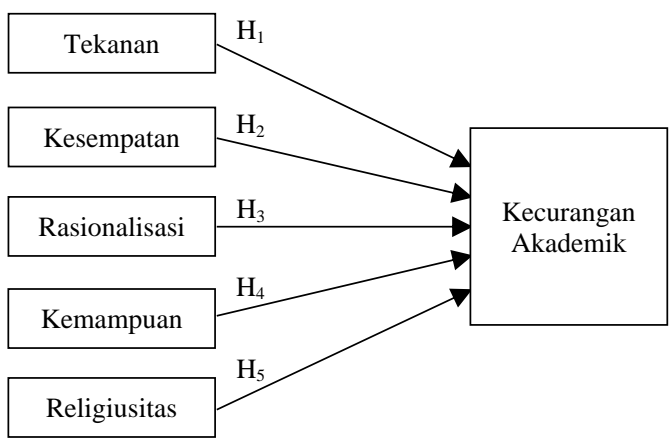

Gambar 1. Model Penelitian

\section{METODE PENELITIAN}

Populasi pada penelitian ini adalah mahasiswa Prodi Akuntansi PTN dan PTS dengan akreditasi A dan B. Peneliti mengambil sampel pada Universitas PGRI Yogyakarta (UPY), Universitas Negeri Yogyakarta (UNY), Universitas Muhammadiyah Yogyakarta (UMY), Universitas Teknologi Yogyakarta (UTY), dan Universitas Sanata Dharma (USD). Penelitian ini menggunakan purposive sampling sebagai metode penentuan sampel yang mempertimbangkan sifat-sifat yang dapat mewakili populasi. Kriteria responden yaitu mahasiswa akuntansi yang sudah menempuh mata kuliah pengauditan II. Adapun alasan penentuan kriteria tersebut dikarenakan pada mata kuliah tersebut mahasiswa sudah mendalami tentang segitiga kecurangan atau fraud triangle sehingga mahasiswa mengetahui kecurangan mulai dari bentuk, pencegahan hingga penyelesaian kecurangan. Jumlah sampel ditentukan 80 responden yang mengacu pada Sekaran (2006) yang mengemukakan bahwa penentuan sampel yang layak adalah 30-500.

Perilaku kecurangan akademik diukur menggunakan indikator yaitu kecurangan saat mengerjakan tugas individu, kecurangan melaksanakan tugas dalam kelompok, dan kecurangan pada saat penyelenggaraan ujian (Murdiansyah dkk., 2017). Tekanan diukur menggunakan indikator yaitu tugas dianggap sukar, 
mahasiswa tidak sanggup memenuhi kriteria lulus, soal ujian sukar, dan kegiatan di luar kuliah yang padat (Murdiansyah dkk., 2017).

Indikator pengukur kesempatan adalah dosen enggan memeriksa plagiasi, dosen tidak merubah soal dalam ujian maupun tugas, mahasiswa mengamati lingkungannya terlibat kecurangan juga, dan dosen tidak mencegah kecurangan (Murdiansyah dkk., 2017). Indikator pengukur rasionalisasi adalah fakultas tidak mendeteksi adanya kecurangan, dosen tidak menjelaskan tentang kriteria kecurangan akademik, dan mahasiswa lain juga melakukan kecurangan akademik (Prawira \& Irianto, 2018).

Kemampuan dalam penelitian ini diukur dengan pelaku memanfaatkan kelemahan pengendalian internal, kepercayaan diri pelaku tinggi, orang lain dapat terpengaruh, dan pelaku kecurangan dapat mengontol stress (Murdiansyah dkk., 2017). Religiusitas diukur dengan indikator dimensi iman, dimensi ibadah, dimensi ilmu, dimensi ihsan, dan dimensi amal (Rahmawati \& Susilawati, 2019).

Penelitian ini menggunakan data primer dengan pengumpulan data melalui kuesioner online kepada responden mahasiswa aktif S1 Akuntansi sehingga mempermudah dan mempercepat dalam pengumpulan data. Pada penelitian ini, total lima variabel dependen dengan total 23 indikator dikembangkan menjadi 58 pertanyaan. Skala pengukuran yang digunakan untuk variabel dependen dan variabel independen dalam penelitian ini dengan menggunakan skala Likert 4 tingkat persetujuan, skor 4 sangat setuju sampai dengan skor 1 sangat tidak setuju.

Data tersebut kemudian dianalisis dengan regresi linear berganda untuk mengetahui arah hubungan antara dua atau lebih variabel independen dan variabel dependen serta dilakukan uji hipotesis parsial (uji t) dan uji hipotesis simultan (uji F). Asumsi-asumsi yang mendasari analisis ini adalah 1) populasi yang akan diteliti berdistibusi normal, 2) tidak ada hubungan linear antara variabel independen dalam model regresi, 3) tidak ada ketidaksamaan varian dari variabel dari residual untuk semua pengamatan pada model regresi.

Oleh karena itu dilakukan uji asumsi klasik seperti normalitas, multikolinearitas, dan heterokedastisitas. Setelah itu, dilakukan uji koefisen determinasi dengan menggunakan Adjusted R Square untuk melihat seberapa besar variabel-variabel bebas mampu menerangkan variasi variabel terikatnya.

\section{HASIL DAN PEMBAHASAN}

Data dalam penelitian ini didapat melalui google form yang disebar pada mahasiswa akuntansi UPY, UNY, UMY, UTY, dan USD. Kuesioner online yang disebar kepada responden sebanyak 100, dengan tingkat pengembalian $80 \%$. Kuesioner yang kembali dapat digunakan untuk analisis data dan pengujian hipotesis, karena semua identitas dan pernyataan diisi lengkap.

Jumlah responden yang paling banyak dalam penelitian ini berasal dari Universitas PGRI Yogyakarta sebesar 34 orang $(42,5 \%)$, selanjutnya Universitas Muhammadiyah Yogyakarta sebesar 15 orang (18,75\%), Universitas Sanata Dharma Yogyakarta sebesar 13 orang (16,25\%), Universitas Negeri Yogyakarta 10 orang (12,5\%), dan yang terakhir Universitas Teknologi Yogyakarta 8 orang $(10 \%)$. Responden dalam penelitian ini didominasi oleh perempuan dengan jumlah 64 orang $(80 \%)$, dan laki-laki berjumlah 16 orang $(20 \%)$.

Hasil pengujian validitas menggunakan pearson correlation menunjukkan bahwa masing-masing item pertanyaan dalam variabel tekanan, kesempatan, rasionalisasi, kemampuan, dan religiusitas adalah valid. Tabel 1 merupakan contoh hasil uji validitas dari variabel tekanan.

Hasil uji reliabilitas pada Tabel 2 menunjukkan bahwa seluruh variabel memiliki reliabilitas > 0,6 yang berarti jawaban terhadap pernyataan kuesioner adalah konsisten atau stabil. 
Tabel 1. Hasil Uji Validitas Variabel Tekanan

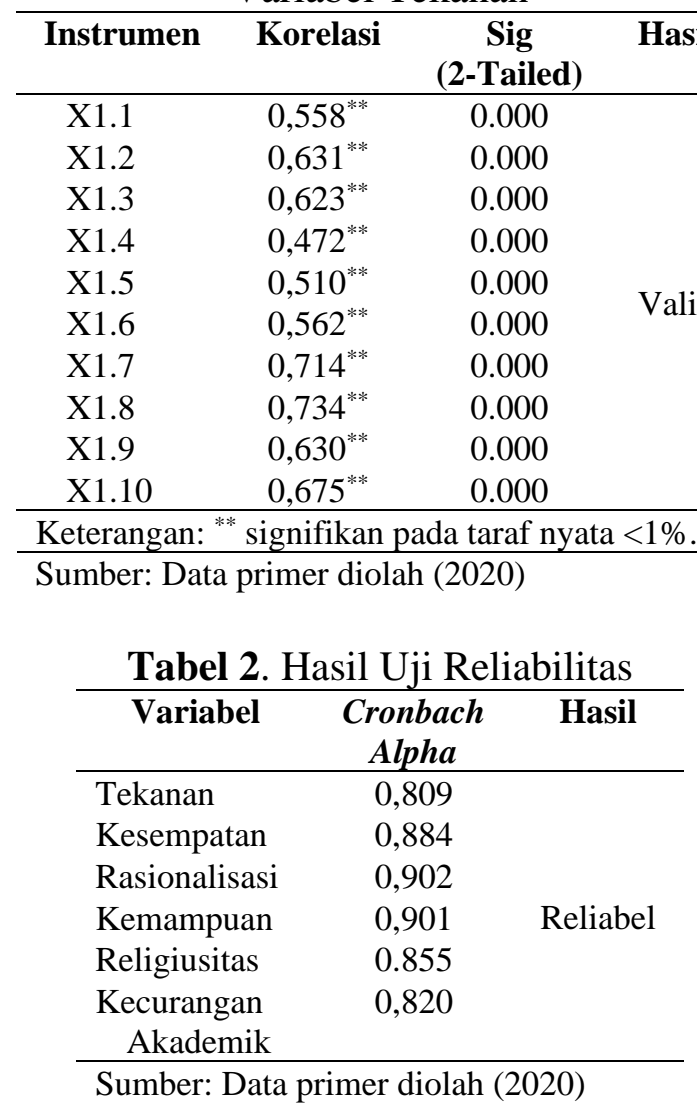

Gambar 2 menunjukkan bahwa pengujian normalitas data menggunakan Kolmogorov Smirnov menghasilkan data menyebar di sekitar histogramnya. Hasil tersebut dapat menunjukkan model regresi ini berdistribusi normal.

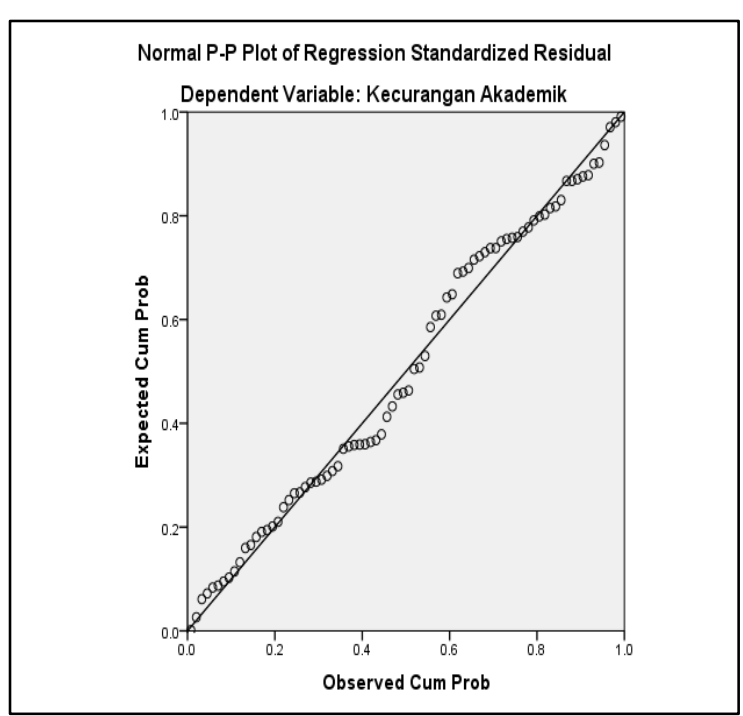

Sumber: Data primer diolah (2020)

Gambar 2. Hasil Uji Normalitas

Dalam penelitian ini analisis regresi linier berganda untuk menguji arah hubungan antara variabel independen (tekanan, kesempatan, rasionalisasi, kemampuan, dan religiusitas) terhadap variabel dependen (kecurangan akademik). Hasil pengujian ditunjukkan pada Tabel 3.

Tabel 3. Hasil Uji Regresi Linear Berganda

\begin{tabular}{lrrrl}
\hline & \multicolumn{1}{c}{ B } & \multicolumn{1}{c}{ t } & Sig & \multicolumn{1}{c}{ Hasil } \\
\hline (constant) & 4,716 & 1,106 & 0,272 & \\
Tekanan & $-0,138$ & $-1,900$ & 0,061 & Tidak didukung \\
Kesempatan & 0,396 & 4,382 & 0,000 & Didukung \\
Rasionalisasi & 0,367 & 4,455 & 0,000 & Didukung \\
Kemampuan & $-0,096$ & $-0,941$ & 0,350 & Tidak didukung \\
Religiusitas & 0,074 & 0,508 & 0,613 & Tidak didukung \\
\hline F Hitung = 40.056 & & & & \\
Sig F = 0.000 & & & \\
Adjustes R Square = 0,712 & & & \\
Signifikasi <5\% & & & \\
Sumber: Data primer diolah (2020)
\end{tabular}

Pengujian hipotesis pertama menunjukkan jika tekanan tidak mempunyai pengaruh terhadap kecurangan akademik mahasiswa, senada dengan Budiman (2018) dan Yudiana \& Lastanti (2016) dan penelitian (Ariani dkk., 2017). Hasil tersebut tidak didukung karena mungkin mahasiswa tidak memiliki alasan utama atau dorongan yang mengharuskan untuk melakukan tindakan kecurangan akademik. Mahasiswa tidak merasa ditekan maupun didorong untuk mendapat IPK yang tinggi baik oleh orang tua maupun pihak kampus. Hal tersebut dapat berasal dari perubahan pola pikir dari orang tua yang paham dampak mendorong anak 
untuk berprestasi dapat menimbulkan stress. Selain itu mahasiswa juga memiliki cukup waktu untuk memahami mata kuliah sehingga tidak merasa bahwa ujian itu suatu hal yang sulit.

Pengujian hipotesis yang kedua menunjukan kesempatan mempunyai pengaruh positif signifikan terhadap kecurangan akademik, senada dengan (Apriani dkk., 2017; Ariani dkk., 2017; Murdiansyah dkk., 2017; Padmayanti dkk., 2017). Hasil tersebut didukung oleh data karena mahasiswa memiliki kondisi yang mendukung dalam melakukan kecurangan akademik. Contohnya saat ujian terdapat kurangnya pengawasan yang dilakukan pengawas ujian yang dapat membuat mahasiswa mendapatkan peluang untuk melakukan kecurangan. Sanksi atau teguran yang kurang tegas dari pengawas membuat mahasiswa tidak takut dan jera dalam berbuat curang. Contoh lainnya pada saat mengerjakan tugas. Kemajuan teknologi yang sangat pesat membuat mahasiswa dengan mudah mendapatkan informasi hingga jawaban tugas dari dosen, membuat mahasiswa ingin mendapatkan jawaban secara instan.

Pengujian hipotesis yang ketiga menunjukkan jika rasionalisasi berpengaruh positif signifikan terhadap kecurangan akademik mahasiswa, senada dengan Apriani dkk. (2017), Budiman (2018), dan Fitriana \& Baridwan (2012). Hasil tersebut didukung oleh data karena mahasiswa merasionalisasikan atau membenarkan perilaku kecurangan yang mereka lakukan. Kecurangan akademik akan menjadi hal yang lumrah untuk dilakukan dan pelaku kecurangan tetap merasa dirinya benar dengan berbuat tidak jujur serta merasa tidak merugikan siapapun. Williams dan Hosek (2003) dalam Yudiana \& Lastanti (2016) berpendapat bahwa mahasiswa membenarkan tindakan kecurangan akademik yang mereka lakukan karena merasa risiko yang mungkin dihadapi tidak sebesar manfaat yang akan didapatkan.
Pengujian hipotesis yang keempat menunjukan jika tidak terdapat pengaruh antara kemampuan dan kecurangan akademik mahasiswa, senada dengan Padmayanti dkk. (2017) dan Zaini dkk. (2015) tidak terbukti didukung oleh data yang ada karena mahasiswa tidak mempunyai keahlian khusus dalam melakukan kecurangan. Keterampilan khusus yang dimaksud adalah pelaku paham tindakan pengawas ujian sehingga mampu memanfaatkan dan mampu mengendalikan diri agar kecurangan yang dilakukan tidak terdeteksi (Prawira \& Irianto, 2018). Wolfe \& Hermanson (2004) menjelaskan bahwa dalam melakukan kecurangan akademik harus diimbangi dengan kemampuan, namun berbeda dengan hasil penilitian ini. Mahasiswa tidak mampu memanfaatkan peluang yang ada untuk melakukan kecurangan, selain itu mahasiswa juga tidak mampu memaksa orang lain untuk melakukan hal yang serupa serta tidak mampu mengelola stres yang ditimbulkan dari perilaku curang.

Pengujian hipotesis yang kelima menunjukan bahwa tidak terdapat pengaruh antara religiusitas dengan kecurangan akademik. Hal ini disebabkan karena mahasiswa dengan tingkat religiusitas tinggi cenderung untuk tidak melakukan kecurangan. Hasil penelitian ini didukung oleh penelitian yang dilakukan Sofyan (2014) pada siswa SMA Negeri 1 Teras Boyolali yang menjelaskan bahwa pelaku melakukan kecurangan akademik karena tidak ingin indeks prestasinya menurun sehingga melakukan beragam cara untuk mendapatkan nilai yang baik, walaupun pada kenyataannya mereka sadar bahwa hal tersebut merupakan tindakan yang tidak baik yang dilarang agamanya. Menurut Skinner (1953) dalam Sofyan (2014) hal tersebut terjadi karena dosa atau hukuman yang diperoleh dari melakukan kecurangan akademik belum dirasakan sekarang. Hukuman sendiri akan efektif apabila dilaksanakan dalam waktu dekat, berbeda dengan hukum agama yang tidak langsung dapat merasakan hukumannya sehingga 
mahasiswa dengan religiusitas tinggi juga memiliki kecenderungan berperilaku curang.

Tabel 3 juga menunjukkan hasil uji $\mathrm{F}$ dan uji koefisien determinasi. Uji statistik $\mathrm{f}$ digunakan untuk mengetahui apakah semua variabel independen mempunyai pengaruh secara bersama-sama terhadap variabel dependen. Hasil analisis Anova Uji F nilai signifikansi F 0,000 lebih kecil dari 0,05. Hal ini menunjukkan bahwa variabel tekanan (X1), kesempatan (X2), rasionalisasi (X3), kemampuan (X4) dan religiusitas (X5) memilki pengaruh simultan terhadap perilaku kecurangan akademik (Y). Uji koefisien determinasi $\left(\mathrm{R}^{2}\right)$ untuk mengetahui seberapa jauh kemampuan model dalam dalam menerangkan variasi variabel. Adjusted R Square sebesar 0,712 hal ini menunjukkan bahwa fraud diamond dan religiusitas berpengaruh $71,2 \%$ terhadap perilaku kecurangan akademik, dan sisanya $28,8 \%$ dipengaruhi oleh variabel lain yang tidak diteliti.

\section{SIMPULAN DAN SARAN}

Terdapat dua analisis yang bisa disimpulkan, yaitu terdapat pengaruh antara kesempatan dan rasionalisasi terhadap terhadap kecurangan akademik namun tekanan, kemampuan, serta religiusitas tidak mempunyai pengaruh pada kecurangan akademik.

Penelitian ini hanya meneliti 1 PTN dan 4 PTS yang terakreditasi A dan B di Yogyakarta. Penelitian ini hanya menggunakan variabel fraud diamond dan religiusitas serta informasi yang didapatkan peneliti kurang mendetail karena hanya didapatkan dari kuesioner. Hal tersebut disebabkan oleh perubahan sistem pembelajaran yang terjadi ditengah pandemi membuat peneliti sulit untuk menyebarkan data pada beberapa universitas, selain itu rendahnya minat mahasiswa untuk mengisi kuisioner membuat data yang diperoleh kurang memadai.
Berdasarkan hasil penelitian ini sebaiknya dapat menjadikan motivasi prodi akuntansi UPY, UNY, UMY, UTY, dan USD untuk meningkatkan pengendalian dan menegakkan sanksi terkait kecurangan akademik guna menjadikan pembelajaran yang optimal. Penelitian ini diharapkan dapat memotivasi mahasiswa agar mampu menjunjung tinggi nilai kejujuran dan tanggung jawab, sehingga dapat memiliki kesadaran untuk tidak melakukan perbuatan curang.

Penelitian selanjutnya sebaiknya memperbanyak responden penelitian tidak hanya terbatas pada 1 Universitas Negeri dan 4 Universitas Swasta, sehingga hasilnya dapat mencerminkan realita yang ada. Penelitian selanjutnya lebih bagus apabila menggunakan variabel yang tidak dijelaskan disini seperti yang terdapat pada teori fraud pentagon, kepribadian, self afficacy, maupun gender (Apriani dkk., 2017). Sehingga dapat menjadikan masukan dalam memperbaiki proses akademik yang lebih optimal. Peneliti selanjutnya juga disarankan tidak hanya menggunakan kuesioner dalam mengumpulkan data, sebaiknya menggunakan wawancara untuk mendapatkan data yang lebih mendetail (Budiman 2018).

\section{REFERENSI}

Albrecht, W. S. \& Albrecht, C. O. (2003). Fraud Examination. Ohio: SouthWestern.

Apriani, N., Sujana, E., \& Sulindawati, I. G. E. (2017). Pengaruh Pressure, Opportunity, dan Rationalization Terhadap Perilaku Kecurnagan Akademik (Studi Empiris: Mahasiswa Akuntansi Program S1 Universitas Pendidikan Ganesha). EJournal S1 Ak Universitas Pendidikan Ganesha, 7(1), 121-133.

Ariani, R., Pusporini, A. Y., \& Priono, H. (2017). Fraud Triangle pada Perilaku Kecurangan Akademik (Studi Pada SMK Negeri 10 Surabaya). Jurnal 
Mebis (Manajemen Dan Bisnis), 3(2), 26-37.

Arifah, W., Setiyani, R., \& Arief, S. (2018). Pengaruh prokrastinasi, tekanan akademik, religiusitas, locus of control terhadap perilaku ketidakjujuran akademik mahasiswa pendidikan akuntansi Unnes. Economic Education Analysis Journal, 7(1), 106-119.

Artani, K. T. B., \& Wetra, I. W. (2017). Pengaruh Academic Self Efficacy Dan Fraud Diamond Terhadap Perilaku Kecurangan Akademik Mahasiswa Akuntansi Di Bali. Jurnal Riset Akuntansi JUARA, 7(2), 123132.

Aziz, M. R., \& Novianti, N. (2016). Analisis Pengaruh Fraud Diamond, Integritas, dan Religiusitas terhadap Perilaku Kecurangan Akademik Mahasiswa [Studi Kasus pada Mahasiswa Akuntansi Konsentrasi Syariah Universitas Brawijaya]. Jurnal Ilmiah Mahasiswa FEB, 4.

Budiman, N. (2018). Faktor-Faktor Yang Mempengaruhi Keputusan Nasabah Untuk Menggunakan Jasa Perbankan Syariah Di Kota Tasikmalaya. Akuntabilitas, 11(1), 75-90.

Cressey, D. (1953). Other people's money; a study in the social psychology of embezzlement. Glencoe: Free Press.

Fitriana, A., \& Baridwan, Z. (2012). Perilaku Kecurangan Akademik Mahasiswa Akuntansi: Dimensi Fraud Triangle. Jurnal Akuntansi Multiparadigma, 3(2), 242-254.

Herlyana, M. V., Sujana, E., \& Prayudi, M. A. (2017). Pengaruh Religiusitas dan Spiritualitas terhadap Kecurangan Akademik Mahasiswa [Studi empiris pada Mahasiswa Universitas Pendidikan Ganesha Singaraja]. Jurnal Akuntansi Program S1, 8(2), 11.

Munirah, A., \& Nurkhin, A. (2018). Pengaruh Faktor-Faktor Fraud Diamond dan Gone Theory Terhadap Kecurangan Akademik. Economics
Development Analysis Journal, 3(1), 120-139.

Murdiansyah, I., Sudarma, M., \& Nurkholis. (2017). Pengaruh Dimensi Fraud Diamond Terhadap Perilaku Kecurangan Akademik. Jurnal Akuntansi Aktual, 4(2), 121-133.

Neila, N. L., Mahsuni, A. W., \& Afifudin, A. (2019). Dampak Dimensi Fraud Diamond pada Perilaku Kecurangan Akademis. Jurnal Ilmiah Riset Akuntansi, 8(08).

Nursani, R., \& Irianto, G. (2013). Perilaku Kecurangan Akademik Mahasiswa: Dimensi Fraud Diamond. Jurnal Ilmiah Mahasiswa FEB, 2(2), 15.

Padmayanti, K. D., Sujana, E., \& Kurniawan, P. S. (2017). Analisis Pengaruh Dimensi Fraud Diamond terhadap Perilaku Kecurangan Akademik Mahasiswa (Studi Kasus Mahasiswa Penerima Bidikmisi Jurusan Akuntansi S1 Fakultas Ekonomi Universitas Pendidikan Ganesha). E-Journal S1 Ak Universitas Pendidikan Ganesha, $8(2), 1-12$.

Prawira, \& Irianto, G. (2018). Analisis Pengaruh Dimensi Fraud Diamond terhadap Perilaku Kecurangan Akademik Mahasiswa. Journal of Chemical Information and Modeling, 53(9), 1689-1699.

Purnamasari, D. (2013). Faktor-faktor yang mempengaruhi kecurangan akademik pada mahasiswa. Educational Psychology Journal, 2(1), 13-21.

Rahmawati, S., \& Susilawati, D. (2019). Pengaruh Dimensi Fraud Diamond Dan Religuisitas Terhadap Perilaku Kecurangan Akademik Mahasiswa. Jurnal Akuntansi Trisakti, 5(2), 269.

Ridhayana, R. (2018). Pengaruh Fraud Triangle dan Tingkat Religiusitas terhadap Kecurangan Akademik [Studi pada mahasiswa S-1 Universitas Khairun]. Jurnal Riset Akuntansi, 5, 112-121.

Ristianingsih, I. (2018). Telaah konsep fraud diamond theory dalam 
mendeteksi perilaku fraud di perguruan tinggi. UNEJ EProceeding, 128-139.

Santoso, D., \& Yanti, H. B. (2016). Pengaruh Perilaku Tidak Jujur Dan Kompetensi Moral Terhadap Kecurangan Akademik (Academic Fraud) Mahasiswa Akuntansi. Jurnal Akuntansi Trisakti, 3(1), 57.

Sekaran, U. (2006). Metodologi penelitian untuk bisnis. Jakarta: Salemba Empat.

Sofyan, B. F. (2014). Hubungan antara Religiusitas dengan Kecurangan Akademik pada Siswa SMA Negeri 1 Teras Boyolali. Skripsi. Universitas Kristen Satya Wacana.

Wolfe, D. T., \& Hermanson, D. R. (2004). The Fraud Diamond: Considering the Four Elements of Fraud. CPA Journal 74.12: 38-42.
Yudiana, A., \& Lastanti, H. (2016). Seminar Nasional dan Call Paper Fakultas Ekonomi UNIBA Surakarta. Jurnal Akuntansi Dan Bisnis, 2, 412422.

Zaini, M., Carolina, A., \& Setiawan, A. R. (2015). Analisis Pengaruh Fraud Diamond dan Gone Theory Terhadap Academic Fraud (Studi Kasus Mahasiswa Akuntansi Se-Madura). Jurnal Promiosi, 4, 1-20.

Zamzam, I., Mahdi, S., \& Ansar, R. (2017). Pengaruh diamond fraud dan tingkat religiuitas terhadap kecurangan akademik (studi pada mahasiswa S-1 di lingkungan perguruan tinggi se kota Ternate). Akuntansi Peradaban, 3, 1-24. 